\title{
Crusted scabies in a patient with systemic disorders - evaluation of ivermectin treatment results
}

\section{Świerzb hiperkeratotyczny u pacjenta z zaburzeniami ogólnoustrojowymi - ocena wyników leczenia iwermektyną}

\author{
Aleksandra Kosmala', Marta Szymoniak-Lipska², Magdalena Jałowska², Marta Dobrzyńska², \\ Monika Bowszyc-Dmochowska², Zygmunt Adamski², Ryszard Żaba'
}

'Department of Dermatology and Venereology, Poznan University of Medical Sciences, Poznan, Poland
2Department of Dermatology, Poznan University of Medical Sciences, Poznan, Poland

'Zakład Dermatologii i Wenerologii, Uniwersytet Medyczny, Poznań, Polska

2Katedra i Klinika Dermatologii, Uniwersytet Medyczny, Poznań, Polska

\section{CORRESPONDING AUTHOR/ ADRES DO KORESPONDENCJI:} lek. Aleksandra Kosmala

Zakład Dermatologii i Wenerologii Uniwersytet Medyczny w Poznaniu ul. Przybyszewskiego 49 60-355 Poznań tel.: +48618691285 e-mail: o.kosmala2@gmail.com

\begin{abstract}
Scabies is a widespread, contagious parasitic disease that affects all socioeconomic groups and was added to the list of WHO Neglected Tropical Diseases. Recent studies indicate misdiagnosis in $45 \%$ of patients with scabies. Crusted scabies is a rare, acute and highly contagious form of scabies infestation, mainly observed in patients with immunosuppression or mental illness. Standard therapy for crusted scabies is a combination of a topical scabicide and oral ivermectin. The aim of the study was to present the case of a 19-year-old male patient with Down syndrome and systemic disorders, who was diagnosed with crusted scabies and successfully treated with ivermectin. We suggest that ivermectin is an effective and safe therapy for crusted scabies treatment. The presented case shows the desirability of ivermectin registration for crusted scabies in Poland.
\end{abstract}

\section{STRESZCZENIE}

Świerzb jest szeroko rozpowszechnioną, zakaźną chorobą pasożytniczą, która występuje we wszystkich grupach społeczno-ekonomicznych. Światowa Organizacja Zdrowia (WHO) umieściła świerzb na liście tzw. neglected tropical diseases (zaniedbanych chorób tropikalnych). Ostatnie badania wskazują, że aż u 45\% pacjentów ze świerzbem stawiana jest błędna diagnoza. Świerzb hiperkeratotyczny jest rzadką, ciężką i bardzo zakaźną postacią świerzbu, która występuje głównie u pacjentów w stanie immunosupresji lub osób z zaburzeniami psychicznymi. Standardowo w leczeniu świerzbu hiperkeratotycznego stosuje się miejscowy lek o działaniu świerzbobójczym w skojarzeniu z iwermektyną stosowaną doustnie. Celem pracy jest przedstawienie przypadku 19-letniego mężczyzny z zespołem Downa i zaburzeniami ogólnoustrojowymi, u którego rozpoznano świerzb hiperkeratotyczny i wdrożono leczenie iwermektyną doustnie z dobrym skutkiem. Wskazujemy, że iwermektyna stanowi skuteczny i bezpieczny środek w leczeniu świerzbu hiperkeratotycznego. Przedstawiony przypadek świadczy o celowości rejestracji w Polsce iwermektyny podawanej ogólnoustrojowo we wskazaniu do leczenia świerzbu hiperkeratotycznego.

Key words: ivermectin, Down syndrome, itch, scabies.

Słowa kluczowe: iwermektyna, zespół Downa, świąd, świerzb. 


\section{INTRODUCTION}

Scabies is a widespread, contagious disease that affects all socio-economic groups. This parasite disease is caused by an arachnid - Sarcoptes scabiei var. hominis $[1,2]$. According to the study Global Burden of Disease conducted in 2015 , it is estimated that more than 200 million people around the world suffer from scabies [3]. The World Health Organisation treats scabies as a Neglected Tropical Disease (NTD) [4]. In 2012, an International Alliance for the Control of Scabies (IACS) was established. It was supported by non-governmental institutions and the WHO $[5,6]$.

Scabies is manifested by skin lesions and intense pruritus, which usually intensifies in the evening and at night. Skin eruptions in the course of infestation with human mites can mimic other dermatological diseases, most often in the form of diagonal or irregular tunnels located within the interdigital spaces, the bending area of the wrists and in the genital area [7]. Scabies is described as a risk factor for the development of acute glomerulonephritis, acute rheumatic fever, and rheumatic heart disease [8,9]. Although scabies is a disease that has been present for centuries in all parts of the world, there is still no reliable laboratory test confirming the diagnosis. The need for standardisation and improvement in the diagnosis of scabies was considered as a priority at the inaugural meeting of the International Alliance for Control of Scabies in Atlanta in 2012 [10]. Currently, the diagnosis of scabies requires microscopic examination of epidermal scrapings to visualise the adult forms of mites, its eggs, or dark brown faeces. However, this test is characterised by low sensitivity (about 50\%) with a high risk of false negative results. Recent reports indicate that $45 \%$ of patients with scabies are misdiagnosed $[11,12]$. Other diagnostic methods are dermatoscopy, confocal reflective microscopy, and videodermatoscopy. By using these techniques the image of triangular, brown structures (the hangglider-like triangle of the mite's head) and serpentine lines (burrows of scabies) described as streaks behind the jet (jet with a contrail) can be visualised $[2,13]$.

Scabies occurs in several varieties; the most severe form is crusted scabies, formerly known as Norwegian scabies because it was first described in leprosy patients in Norway in 1848. Crusted scabies is a rare, acute, and highly contagious form of scabies infestation. Crusted scabies occurs in patients with neurological and cognitive disorders, in immunocompromised patients such as HIV carriers, human T-lymphotropic virus carriers, and patients with drug-induced immunosuppression. This form of scabies is also observed in patients with chronic kidney disease, in elderly patients, or in people who abuse psychoactive substances [14]. In patients with scabies,

\section{WPROWADZENIE}

Świerzb jest szeroko rozpowszechnioną chorobą zakaźną, która występuje we wszystkich grupach społeczno-ekonomicznych. Chorobę wywołuje pasożyt - świerzbowiec ludzki Sarcoptes scabiei var. hominis należący do gromady pajęczaków $[1,2]$. Według badania dotyczącego globalnego obciążenia chorobami (Global Burden of Disease) przeprowadzonego w 2015 roku szacuje się, że na świerzb choruje ponad 200 milionów ludzi na świecie [3]. Światowa Organizacja Zdrowia (World Health Organisation - WHO) umieściła świerzb na liście tzw. zaniedbanych chorób tropikalnych (neglected tropical diseases) [4]. W 2012 roku powołano Międzynarodowy Związek na rzecz Zwalczania Świerzbu (International Alliance for the Control of Scabies - IACS). Inicjatywa jest wspierana przez instytucje pozarządowe oraz WHO [5, 6].

Do najbardziej charakterystycznych objawów świerzbu należą intensywny świąd, który zwykle nasila się w godzinach wieczornych i nocnych, oraz zmiany skórne. Zmiany skórne w przebiegu zakażenia świerzbowcami mogą naśladować inne schorzenia dermatologiczne. Mają one najczęściej postać przecinkowatych lub nieregularnych tuneli świerzbowcowych zlokalizowanych głównie w obrębie przestrzeni międzypalcowych rąk, na powierzchni zgięciowej nadgarstków i w obrębie narządów płciowych [7]. Świerzb jest opisywany jako czynnik ryzyka rozwoju ostrego kłębuszkowego zapalenia nerek, ostrej gorączki reumatycznej i choroby reumatycznej serca $[8,9]$. Świerzb występuje od wieków we wszystkich częściach świata, jednak nadal nie opracowano wiarygodnych testów laboratoryjnych potwierdzających rozpoznanie. Standaryzacja i poprawa diagnostyki świerzbu została uznana za priorytet podczas kongresu inauguracyjnego IACS w Atlancie w 2012 roku [10]. Obecnie w diagnostyce świerzbu stosuje się badanie mikroskopowe zeskrobin naskórka w celu wykrycia dorosłych form świerzbowców, ich jaj albo brunatnych odchodów. Metoda ta charakteryzuje się jednak niską czułością (ok. 50\%) i wysokim ryzykiem uzyskania wyników fałszywie ujemnych. Najnowsze badania wskazują, że aż u 45\% pacjentów ze świerzbem rozpoznanie jest błędne [11, 12]. Inne metody diagnostyczne obejmują dermatoskopię, refleksyjną mikroskopię konfokalną i wideodermatoskopię. Techniki te umożliwiają wizualizację trójkątnych, brązowych struktur (głowy pasożyta przypominającej trójkątną lotnię) i linii przypominających serpentyny (nor świerzbowców) porównywanych $\mathrm{w}$ piśmiennictwie $\mathrm{z}$ kształtem odrzutowca ze smugą dymu $[2,13]$.

Świerzb występuje w kilku odmianach. Najcięższą z nich jest świerzb hiperkeratotyczny, dawniej określany również jako świerzb norweski, ponieważ 
due to the lack of a proper immune response, intense multiplication of parasites may occur. High levels of total IgE and peripheral eosinophilia are noticeable. Thick, stratified scales are present over the skin of the entire body. The clinical picture resembles psoriasis $[2,14-16]$. In the treatment of crusted scabies, topical scabicidal therapy and oral ivermectin are used [17].

\section{OBJECTIVE}

We present a case of a 19-year-old patient with Down syndrome, who was hospitalised due to crusted scabies and was successfully treated with oral ivermectin.

\section{CASE REPORT}

A 19-year-old, male patient with Down syndrome was admitted to the Department of Dermatology with the diagnosis of erythroderma. The medical history was provided by the patient's mother. Skin lesions developed 6 months prior to hospitalisation initially only the hands were affected. The GP suspected the diagnosis of scabies. The patient was treated with topical permethrin 5\% cream. On the day of admission, numerous fissures localised in the skin of the neck and the inner surface of the wrists were found.

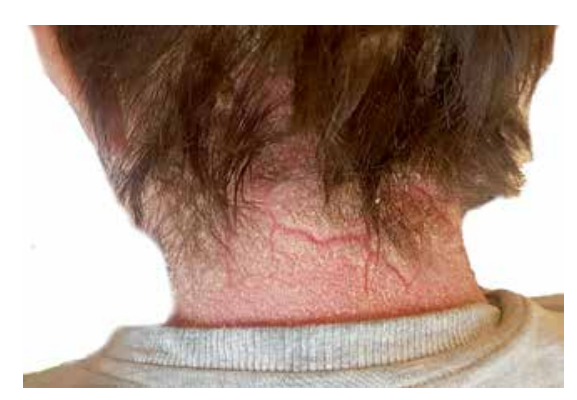

Figure I. Erythema and fissures within the neck

Rycina I. Rumień i rozpadliny w obrębie karku

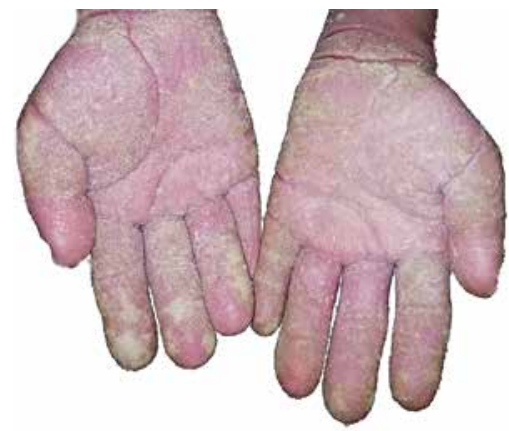

Figure 3. Scales, yellow scabs, and fissures within the hand and the inner surface of the wrists

Rycina 3. Łuska, żółte strupy oraz rozpadliny w obrębie dłoni i wewnętrznej powierzchni nadgarstków został opisany po raz pierwszy u chorych na trąd w Norwegii w 1848 roku. Świerzb hiperkeratotyczny jest rzadką, ciężką i bardzo zakaźną postacią zakażenia świerzbem. Świerzb hiperkeratotyczny występuje u osób z zaburzeniami neurologicznymi i poznawczymi, u pacjentów o obniżonej odporności, m.in. u nosicieli wirusa HIV i ludzkiego wirusa T-limfotropowego, a także u pacjentów z immunosupresją indukowaną lekami. Tę postać świerzbu obserwuje się również u osób z przewlekłą chorobą nerek, w podeszłym wie$\mathrm{ku}$ lub nadużywających substancji psychoaktywnych [14]. U tych chorych ze względu na brak prawidłowej odpowiedzi immunologicznej może dochodzić do intensywnego namnażania się pasożytów. Obserwuje się wysoki poziom całkowitego IgE oraz eozynofilię krwi obwodowej. Na skórze całego ciała widoczna jest zgrubiała, nawarstwiona łuska. Obraz kliniczny przypomina łuszczycę [2, 14-16]. W leczeniu świerzbu hiperkeratotycznego stosuje się miejscowe leki o działaniu świerzbobójczym oraz iwermektynę doustnie [17].

\section{CEL PRACY}

W pracy przedstawiono przypadek 19-letniego pacjenta z zespołem Downa, hospitalizowanego z powodu świerzbu hiperkeratotycznego. U chorego wdrożono leczenie iwermektyną doustnie z dobrym skutkiem.

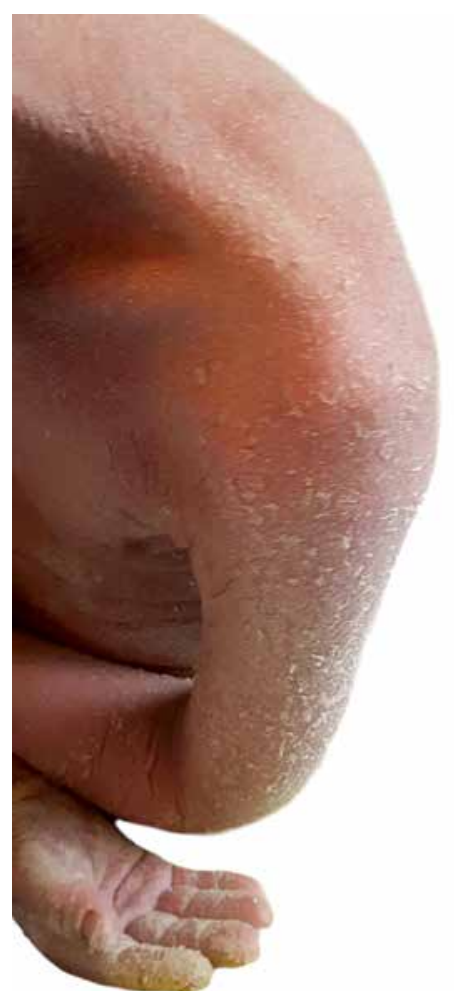

Figure 2. Erythema, extensive exfoliation of the epidermis within the upper extremity

Rycina 2. Rumień i złuszczanie naskórka w obrębie kończyny górnej 
Also, thick scales in the skin of the upper and lower extremities were present (figs. 1-3). Skin lesions were accompanied by pruritus. The physical examination revealed the patient to be apathetic, hypotrophic, underweight, and tachycardic (up to 140 beats/min). Also, lower limb oedema was present. Numerous erythematous papules and excoriations were found on the skin of the patient's mother. According to mother the other members of the family also presented with similar skin lesions and pruritus. The socio-economic conditions and related limited hygienic and sanitary facilities (e.g. no bathroom in the apartment) and possibilities were significant for the diagnosis.

A microscopic examination of the scraping scales revealed the presence of numerous forms of mites (mature forms, larvae, eggs) in both samples - patients's and mother's (figs. 4, 5). The diagnosis of crusted scabies was established.

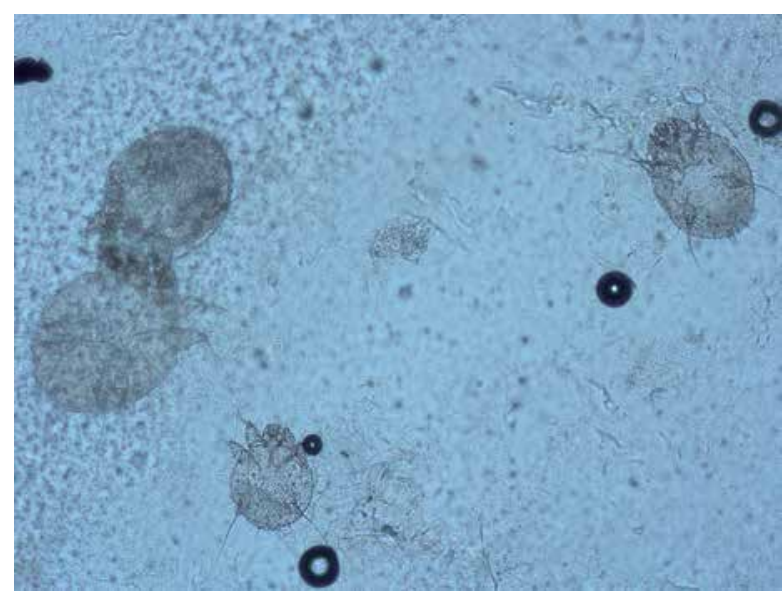

Figure 4. Numerous mature forms of mites, light microscope, magnification I0X

Rycina 4. Liczne osobniki dojrzałe świerzbowca, mikroskop świetlny, powiększenie I0X

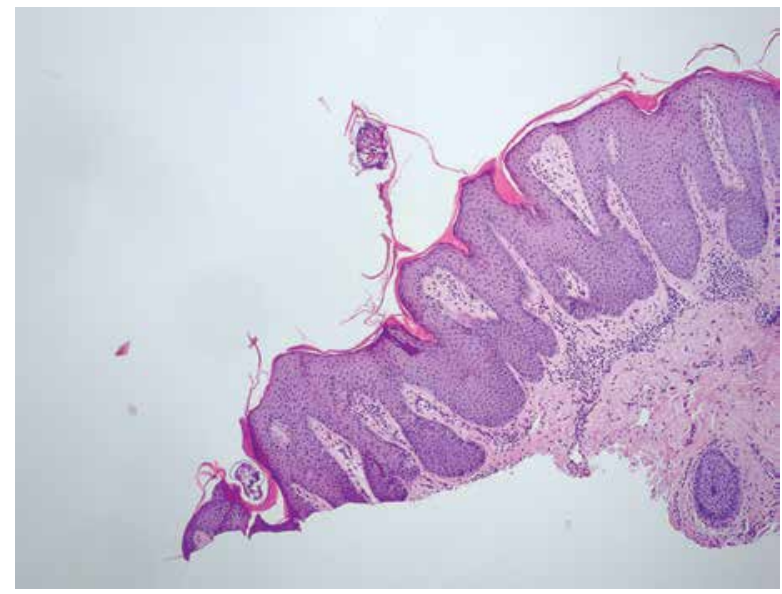

Figure 6. Two mites in the stratum corneum, re-thickened epidermis, $H+E$ stain, magnification $40 x$

Rycina 6. Dwa świerzbowce w warstwie rogowej, odczynowo pogrubiały naskórek, barwienie $\mathrm{H}+\mathrm{E}$, powiększenie $40 \times$

\section{OPIS PRZYPADKU}

Mężczyzna 19-letni z zespołem Downa został przyjęty do Kliniki Dermatologii z rozpoznaniem erytrodermii. Wywiad zebrano od matki pacjenta. Zmiany skórne pojawiły się 6 miesięcy przed hospitalizacją i początkowo obejmowały wyłącznie powierzchnię rąk. Lekarz pierwszego kontaktu wysunął podejrzenie świerzbu i zalecił leczenie miejscowe kremem $\mathrm{z}$ permetryną $5 \%$. W dniu przyjęcia do kliniki u chorego stwierdzono liczne rozpadliny umiejscowione na skórze szyi i wewnętrznych powierzchniach nadgarstków. Widoczna była również gruba łuska na skórze kończyn górnych i dolnych (ryc. 1-3). Zmianom skórnym towarzyszył świąd. W badaniu przedmiotowym u pacjenta stwierdzono hipotrofię, niedowage i tachykardię (do 140 uderzeń na minutę). Pacjent był apatyczny. Obecny był również obrzęk kończyn dol-

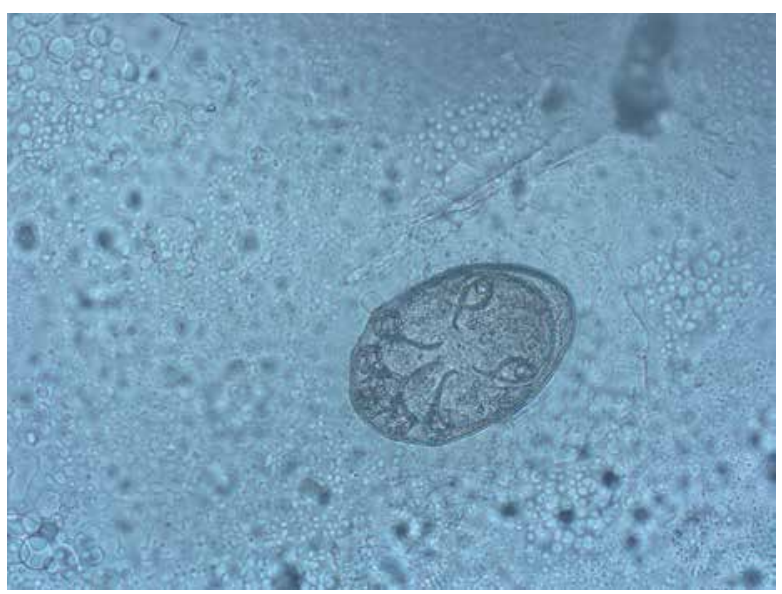

Figure 5. Larval form of mite, light microscope, magnification $20 \times$ Rycina 5. Postać larwalna świerzbowca, mikroskop świetlny, powiększenie $20 x$

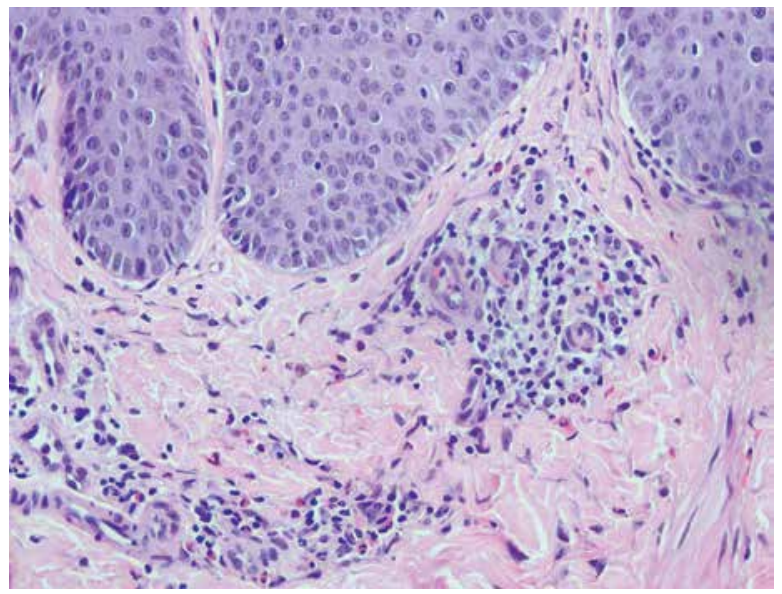

Figure 7. Inflammatory infiltration with eosinophils under the epidermis, $H+$ E stain, magnification $200 x$

Rycina 7. Naciek zapalny z eozynofilami pod naskórkiem, barwienie $\mathrm{H}+\mathrm{E}$, powiększenie 200x 


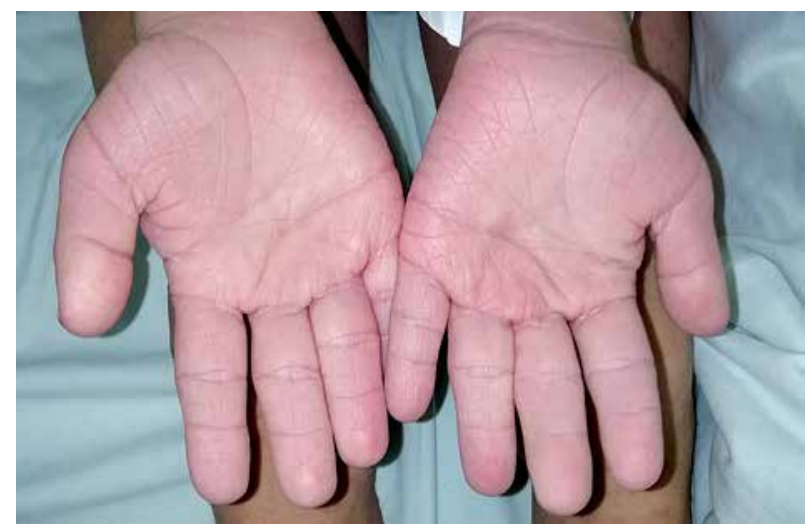

Figure 8. Patient's hand after treatment

Rycina 8. Dłonie pacjenta po zakończonym leczeniu

Conventional histopathological examination confirmed the diagnosis (figs. 6, 7). Complete blood count and other laboratory tests revealed increased C-reactive protein values $(45.2 \mathrm{mg} / \mathrm{l})$, elevated thyrotropin hormone, iron deficiency, reduced total protein level, and hypoalbuminaemia with hypergammaglobulinaemia. In immunofixation no monoclonal protein was present.

Numerous specialist consultations were carried out during the hospitalisation. The endocrinological consultation showed hypothyroidism; therefore, hormonal supplementation was ordered. After the gastroenterological consultation, due to the reduced total protein level, a high-energy diet was recommended. Due to the swelling of the lower limbs and the accompanying tachycardia, an echocardiogram was performed. The pericardial fluid was found with no tamponade features. Because fibrous lesions in the lungs were found in the chest $X$-ray, thoracic computer tomography was performed. The presence of pericardial fluid and emphysema in the lungs was confirmed as a result. The Quantiferon-TB Gold test was negative.

Due to the extent and severity of skin lesions, general antimicrobial and anti-inflammatory treatment was ordered (doxycycline at a dose of $200 \mathrm{mg} /$ day orally). For the topical treatment, initially sulphur ointment was used $(2.5 \%$ to $5 \%$ together with borate cream), then permethrin $5 \%$ cream was applied. Due to the disease intensity, consultations of tropical and parasitic diseases were conducted. Systemic therapy in the form of oral ivermectin was applied at a dose of $200 \mu \mathrm{g} / \mathrm{kg}$ b.w., twice in an interval of 7 days. Significant improvement was observed after the treatment. The patient's mother was treated with a topical sulphur $10 \%$ ointment. The control test of epidermal scrapings in microscopic examination after treatment did not reveal any developmental or mature forms of scabies. After completing the dermatological treatment, the photographic documentation was compiled (fig. 8). The patient was transferred to Cardiology nych. Na skórze matki pacjenta występowały liczne rumieniowe grudki i przeczosy. Według matki u innych członków rodziny obecne były podobne zmiany skórne oraz świąd. Istotne znaczenie dla rozpoznania miały społeczno-ekonomiczne warunki życia pacjenta i związane z nimi ograniczone możliwości higieniczno-sanitarne (m.in. brak łazienki w mieszkaniu).

Badanie mikroskopowe zeskrobin pobranych z obszaru pokrytego łuską wykazało obecność świerzbowców w różnych postaciach (osobników dojrzałych, larw, jaj) w obu próbkach - pacjenta i matki (ryc. 4, 5). $\mathrm{Na}$ tej podstawie ustalono rozpoznanie świerzbu hiperkeratotycznego.

Diagnozę potwierdzono, wykonując standardowe badanie histopatologiczne (ryc. 6, 7). Badania laboratoryjne wykazały podwyższone wartości białka C-reaktywnego (45,2 mg/l), zwiększone stężenie hormonu tyreotropowego, niedobór żelaza, obniżony poziom białka całkowitego oraz hipoalbuminemię z hipergammaglobulinemią. $W$ immunofiksacji nie wykryto białka monoklonalnego.

W trakcie hospitalizacji przeprowadzono liczne konsultacje specjalistyczne. Ze względu na odchylenia w badaniach dodatkowych rozpoznano niedoczynność tarczycy i wdrożono suplementację hormonalną. Po konsultacji gastroenterologicznej, z uwagi na obniżony poziom białka całkowitego, zalecono wprowadzenie diety wysokoenergetycznej. Ze względu na obrzęk kończyn dolnych z towarzyszącą tachykardią wykonano badanie echokardiograficzne, w którym stwierdzono obecność płynu w worku osierdziowym, bez cech tamponady. W badaniu RTG klatki piersiowej wykazano zmiany włókniste w płucach, poszerzono więc diagnostykę o tomografię komputerową klatki piersiowej, potwierdzając obecność płynu w worku osierdziowym i wykazując rozedmę płuc. Test Quantiferon TB Gold dał wynik ujemny.

Ze względu na rozległość i znaczne nasilenie zmian skórnych wdrożono ogólne leczenie przeciwbakteryjne i przeciwzapalne (doksycyklina doustnie w dawce 
Clinic for further diagnostics of the presence of pericardial fluid. Because of hypergammaglobulinaemia, the presence of free $\kappa$ and $\lambda$ chains in the serum, and the presence of Bence Jones protein in urine, a lymphoproliferative disease was suspected. The patient was referred for further hospital diagnostics in the Haemato-oncology Department.

\section{DISCUSSION}

Crusted scabies (formerly known as Norwegian scabies) is a rare and severe form of scabies characterised by high infectivity resulting from massive infestation with human mites. The disease occurs in immunocompromised people, such as patients with acquired immunodeficiency syndrome (AIDS), in patients with neoplastic diseases, neurological diseases involving weakness of sensation or immobility with a reduced possibility of scratching, patients during therapy with immunosuppressive drugs, or patients with mental retardation, including Down syndrome [18-23]. Clinically crusted scabies is characterised by the presence of extensive, hyperkeratotic scales with yellowish-green crusts with a particular intensity within the torso, limbs, face, and scalp [17, 24]. Pruritus of the skin may be absent or have minor severity. The most common complications of scabies are secondary bacterial infections, including impetigo.

Establishing an unambiguous diagnosis of scabies requires the identification of adult forms of mites, eggs, or faeces in microscopic examination of the skin epidermis. It should be remembered that a negative result of the study does not exclude the diagnosis of scabies $[25,26]$. In patients with crusted scabies diagnosis for immunodeficiency disorders and sexually transmitted diseases should be made [27].

The standard therapy for crusted scabies is a combination of topical scabicidal preparations and oral ivermectin [17]. Ivermectin was first approved as a parasiticide with a broad spectrum of activity in veterinary medicine; currently its use is approved in many countries also for humans - in the treatment of nematodes and ectoparasites infections. Ivermectin is currently the only oral antiparasitic medicine available on the market and is used mainly in the treatment of scabies, crusted scabies, and patients who may not follow the recommendations (low compliance) [28]. In Poland, oral ivermectin is currently available only for target import. The European guidelines for the management of scabies in the treatment of crusted scabies recommend topical use of scabicidal preparations (5\% permethrin in cream or $25 \%$ benzyl benzoate) daily for 7 days, then two times a week until cure, and use of oral ivermectin at a dose of $200 \mu \mathrm{g} /$ $\mathrm{kg}$ on the first, second, and eighth day of treatment. In severe form of scabies, when microscopic control
$200 \mathrm{mg}$ /dobę). W leczeniu miejscowym zastosowano początkowo maść siarkową (od 2,5\% do 5\% łącznie $\mathrm{z}$ kremem bornym), a następnie krem zawierający 5\% permetryny. Przeprowadzono konsultację w zakresie chorób tropikalnych i pasożytniczych. Wprowadzono leczenie ogólnoustrojowe iwermektyną doustnie w dawce $200 \mu \mathrm{g} / \mathrm{kg}$ m.c., podawaną dwukrotnie w odstępie 7 dni. Po leczeniu zaobserwowano istotną poprawę. U matki pacjenta zastosowano miejscowo maść siarkową 10\%, uzyskując poprawę. Kontrolne badanie mikroskopowe zeskrobin naskórkowych po zakończeniu terapii u pacjenta i jego matki nie wykazało postaci rozwojowych ani dojrzałych świerzbowców. Po zakończeniu leczenia dermatologicznego opracowano dokumentację fotograficzną (ryc. 8). Chory został przekazany do Kliniki Kardiologii w celu dalszej diagnostyki nagromadzenia płynu w worku osierdziowym. Z powodu hipergammaglobulinemii, obecności wolnych łańcuchów typu $\kappa$ i $\lambda$ w surowicy oraz białka Bence'a-Jonesa w moczu powzięto podejrzenie choroby limfoproliferacyjnej. Pacjent został skierowany na dalszą diagnostykę na oddział onkologiczno-hematologioczny.

\section{OMÓWIENIE}

Świerzb hiperkeratotyczny (dawniej znany jako świerzb norweski) jest rzadką i ciężką formą świerzbu cechującą się wysoką zakaźnością. Choroba pojawia się wskutek masowego zakażenia skóry świerzbowcem ludzkim i występuje u osób o obniżonej odporności, m.in. chorych na AIDS (zespół nabytego niedoboru odporności), choroby nowotworowe, zaburzenia neurologiczne przebiegające $\mathrm{z}$ osłabieniem czucia lub brakiem mobilności, a także ograniczeniem możliwości drapania, jak również u pacjentów poddanych terapii lekami immunosupresyjnymi lub z opóźnieniem umysłowym, m.in. zespołem Downa [18-23]. Objawy kliniczne świerzbu hiperkeratotycznego obejmują rozległe zmiany pokryte hiperkeratotyczną łuską z żółtawo-zielonymi strupami o największym nasileniu w obrębie tułowia, kończyn, twarzy i owłosionej skóry głowy $[17,24]$. Świąd może być nieobecny lub występować w niewielkim nasileniu. Najczęstszym powikłaniem świerzbu są wtórne zakażenia bakteryjne, między innymi liszajec zakaźny.

Ustalenie jednoznacznego rozpoznania wymaga wykrycia dojrzałych postaci świerzbowców, jaj albo kału w badaniu mikroskopowym naskórka. Należy jednak pamiętać, że ujemny wynik badania nie wyklucza rozpoznania świerzbu $[25,26]$. U chorych ze świerzbem hiperkeratotycznym powinno się także przeprowadzić diagnostykę w kierunku niedoborów odporności i chorób przenoszonych drogą płciową [27].

Standardowe leczenie świerzbu hiperkeratotycznego obejmuje miejscowy lek o działaniu świerzbobójczym w skojarzeniu z iwermektyną stosowaną doustnie [17]. Iwermektyna została po raz pierwszy zarejestrowana 
examination gives positive results, it is advisable to provide additional treatment with ivermectin on the ninth and $15^{\text {th }}$ day or on days $9,15,22$, and 29 . Ivermectin should not be used in pregnant women and children weighing less than $15 \mathrm{~kg}$ [17].

Apart from pharmacological treatment, the appropriate procedure should be provided: clothes should be washed in a minimum $50^{\circ} \mathrm{C}$ or placed in plastic bags for a minimum of 7 days. At the same time, all household members should be treated regardless of their clinical symptoms. Patients with crusted scabies should be isolated until the end of therapy [29]. An infestation is considered cured if no new lesions appear after 1 week after the end of treatment and no pruritus occurs; however, pruritus after treatment may persist for 2-4 weeks [17].

There are many reports in the literature confirming the efficacy of ivermectin in the treatment of crusted scabies. Fonseca et al. [22] present a case of a 3-yearold girl with Down syndrome, in whom crusted scabies was incorrectly diagnosed as erythrodermic psoriasis. As a result of treatment with a cyclosporin at a dose of $5 \mathrm{mg} / \mathrm{kg} \mathrm{b.w./day,} \mathrm{the} \mathrm{dermatological}$ state worsened, with hyperkeratosis of the elbows, knees, and plantar surfaces of the feet. Only the inclusion of $5 \%$ permethrin in cream and ivermectin at a dose of $200 \mu \mathrm{g} / \mathrm{kg}$ b.w. once a week for four weeks significantly improved the hyperkeratotic changes and pruritus. Although the U.S. Food and Drug Administration does not allow ivermectin to be used in patients under five years of age [30], the described case shows the validity of using the drug in severe cases of scabies in young children. Similarly, the use of ivermectin in the case of crusted scabies induced by intense local glucocorticoid therapy in a 2-year-old boy resulted in a complete remission of pruritus within 24 hours and a significant improvement in dermatological status within 72 hours. The therapy was described as well tolerated and safe [31].

Corbett et al. [32] describe the importance of ivermectin treatment in the prevention of hospital scabies epidemics. In the case of a HIV-infected patient with crusted scabies, who received only local treatment, it did not have a positive effect and the patient remained contagious for several weeks. Out of 19 people from the medical staff who had contact with the patient, 14 people reported symptoms characteristic for scabies. It was only the combination of topical treatment (malathion) with oral ivermectin at the dose of $200 \mu \mathrm{g} / \mathrm{kg}$ b.w. that resulted in the cure of scabies. Modification of the infection control policy within the ward was implemented, i.e. stricter care and isolation procedures were introduced. Another HIV-positive patient who showed signs of crusted scabies received a combination therapy: oral ivermectin and topical scabicidal medicines at an early stage of treatment. As jako środek pasożytobójczy o szerokim spektrum działania w weterynarii, jednak obecnie jest także zarejestrowana w wielu krajach we wskazaniu do leczenia zakażeń nicieniami i ektopasożytami u ludzi. Iwermektyna jest aktualnie jedynym dostępnym na rynku doustnym lekiem przeciwświerzbowcowym. Stosuje się ją głównie w leczeniu świerzbu i świerzbu hiperkeratotycznego oraz u chorych, którzy w niskim stopniu przestrzegają zaleceń terapeutycznych [28]. W Polsce iwermektyna w postaci doustnej jest dostępna wyłącznie w ramach importu docelowego. Wytyczne europejskie zalecają leczenie świerzbu hiperkeratotycznego miejscowymi preparatami świerzbobójczymi (krem z permetryną $5 \%$ lub benzoesan benzylu 25\%) stosowanymi codziennie przez $7 \mathrm{dni}$, a następnie 2 razy w tygodniu do czasu wyleczenia, a także terapię iwermektyną doustnie w dawce $200 \mu \mathrm{g} / \mathrm{kg}$ w 1., 2. i 8. dniu leczenia. W ciężkiej postaci świerzbu, gdy mikroskopowe badanie kontrolne daje wynik dodatni, wskazane jest dodatkowe leczenie iwermektyną w 9. i 15. dniu lub w 9., 15., 22. i 29. dniu. Iwermektyny nie należy stosować u kobiet w ciąży ani u dzieci o masie ciała poniżej $15 \mathrm{~kg}$ [17].

Oprócz leczenia farmakologicznego należy zadbać o odpowiednią procedurę pielęgnacyjną. Odzież należy wyprać w temperaturze minimum $50^{\circ} \mathrm{C}$ lub umieścić w workach plastikowych na co najmniej $7 \mathrm{dni}$. Poza tym leczeniu należy poddać wszystkie osoby zamieszkujące we wspólnym gospodarstwie domowym, niezależnie od występowania objawów klinicznych. Pacjenci ze świerzbem hiperkeratotycznym powinni być izolowani do konca leczenia [29]. Zakażenie uznaje się za wyleczone, jeśli po tygodniu od zakończenia terapii nie wystąpią nowe zmiany chorobowe i nie pojawi się świąd, choć świąd po leczeniu może się utrzymywać przez 2-4 tygodni [17].

W piśmiennictwie można znaleźć wiele doniesień potwierdzających skuteczność iwermektyny w leczeniu świerzbu hiperkeratotycznego. Fonseca i wsp. [22] przedstawiają przypadek 3-letniej dziewczynki z zespołem Downa, u której świerzb hiperkeratotyczny został błędnie rozpoznany jako erytrodermia łuszczycowa. Wskutek leczenia cyklosporyną w dawce $5 \mathrm{mg} / \mathrm{kg}$ m.c./dobę stan skóry pacjentki uległ pogorszeniu. Stwierdzono wzmożone rogowacenie naskórka (hiperkeratozę) w okolicy łokci, kolan i na powierzchniach podeszwowych stóp. Dopiero po włączeniu kremu z permetryną 5\% i iwermektyny w dawce $200 \mu \mathrm{g} / \mathrm{kg}$ m.c. raz w tygodniu przez 4 tygodnie zaobserwowano istotne zmniejszenie zmian hiperkeratotycznych i złagodzenie świądu. Chociaż amerykańska Agencja Żywności i Leków nie dopuszcza stosowania iwermektyny u pacjentów poniżej 5 . roku życia [30], opisany przypadek wskazuje na zasadność stosowania tego leku w ciężkich przypadkach świerzbu u małych dzieci. Podobnie w przypadku świerzbu hiperkeratotycznego indukowanego intensywnym miejscowym leczeniem glikokortykosteroidami u 2-letniego chłopca zastosowanie iwermektyny doustnie spowo- 
a result, no hospital infection occurred and a positive scabicidal treatment result was obtained quickly.

\section{CONCLUSIONS}

The presented case is an interesting example of the occurrence of severe scabies - crusted scabies in a patient with Down syndrome, who was suspected of lymphoproliferative disease. It also shows the efficacy of oral ivermectin treatment. Despite severe infestation, confirmed in the extremely positive microscopy examination of epidermal scrapings, an effective therapy combining oral and local preparations was used, which not only led to curing the patient, but also helped to prevent secondary infections between patients and medical staff. Owing to the quick and effective therapy, it was possible to transfer the patient to the Cardiology Department to continue the diagnostic process and treatment. The presented case illustrates the efficacy of using oral ivermectin and the desirability of its registration for treatment of scabies infestations also in Poland.

\section{CONFLICT OF INTEREST}

The authors declare no conflict of interest. dowało całkowite ustąpienie świądu w czasie 24 godzin i znaczną poprawę stanu dermatologicznego w czasie 72 godzin. Zgodnie z doniesieniem leczenie było dobrze tolerowane i bezpieczne [31].

Corbett i wsp. [32] analizowali skuteczność iwermektyny w zapobieganiu szpitalnym epidemiom świerzbu. U pacjenta zakażonego wirusem HIV, u którego stwierdzono świerzb hiperkeratotyczny, leczenie miejscowe zakończyło się niepowodzeniem, a chory był zakaźny przez kilka tygodni. Spośród 19 członków personelu medycznego, którzy mieli z nim kontakt, 14 osób zgłosiło objawy charakterystyczne dla świerzbu. Dopiero terapia miejscowa (malation) w skojarzeniu z iwermektyną stosowaną doustnie w dawce $200 \mu \mathrm{g} / \mathrm{kg}$ m.c. umożliwiła pełne wyleczenie. Na oddziale wprowadzono zmodyfikowane zasady kontroli zakażeń, tj. zaostrzono procedury opieki i izolacji pacjentów. U innego pacjenta HIV-pozytywnego z objawami świerzbu hiperkeratotycznego wdrożono terapię skojarzoną (iwermektynę doustnie i miejscowe leki o działaniu przeciwświerzbowcowym) na wczesnym etapie leczenia. Dzięki temu nie doszło do zakażenia szpitalnego i szybko uzyskano skuteczny efekt świerzbobójczy.

\section{WNIOSKI}

Przedstawiony przypadek jest interesującym przykładem ciężkiej postaci świerzbu - świerzbu hiperkeratotycznego - $\mathrm{u}$ pacjenta $\mathrm{z}$ zespołem Downa, u którego podejrzewano chorobę limfoproliferacyjną. Potwierdza również skuteczność leczenia iwermektyną doustnie. Pomimo nasilonego zakażenia świerzbowcami, które jednoznacznie potwierdzono w badaniu mikroskopowym zeskrobin naskórka, leczenie skojarzone preparatami doustnymi i miejscowymi przyniosło dobry skutek. Dzięki temu nie tylko osiągnięto pełne wyleczenie, lecz także skutecznie wyeliminowano ryzyko przeniesienia zakażenia z pacjentów na personel medyczny. Dzięki szybkiemu i skutecznemu leczeniu możliwe było przeniesienie pacjenta do Kliniki Kardiologii w celu kontynuowania procesu diagnostycznego i terapeutycznego. Przedstawiony przypadek potwierdza skuteczność doustnej iwermektyny i wskazuje na celowość rejestracji leku w leczeniu zakażeń świerzbem także w Polsce.

\section{KONFLIKT INTERESÓW}

Autorzy nie zgłaszają konfliktu interesów.

\section{References}

\section{Piśmiennictwo}

1. Heukelbach J., Feldmeier H.: Scabies. Lancet 2006, 367, 1767-1774.

2. Kosmala A., Żaba R., Adamski Z.: Świerzb - wielki naśladowca? Najnowsze doniesienia dotyczące świerzbu oraz opis przypadku. Derm Prakt 2017, 9, 43-51.

3. GBD 2015 Disease and Injury Incidence and Prevalence Collaborators: Global, regional, and national incidence, prevalence, and years lived with disability for 310 diseases and injuries, 1990-2015: a systematic analysis for the Global Burden of Disease Study 2015. Lancet 2016, 388, 1545-1602. 
4. World Health Organization: Report of the tenth meeting of the WHO Strategic and Technical Advisory Group for neglected tropical diseases. 2017. Available from: https://www.who.int/neglected_diseases/NTD_STAG_report_2017.pdf?ua=1.

5. Kowalska M., Kowalik A., Góźdź S.: Health problems in developing countries: scabies infection as a neglected tropical disease. Przegl Dermatol 2014, 101, 490-499.

6. Hay R.J., Steer A.C., Chosidow O., Currie R.J.: Scabies a suitable case for global control initiative. Curr Opin Infect Dis 2013, 26, 107-109.

7. Burgdorf W.H.C., Plewig G., Wolff H., et al.: Świerzb. [In:] Braun-Falco. Dermatologia. W.H.C. Burgdorf, G. Plewig, H. Wolff, et al.: (eds.). Czelej, Lublin, 2010, 345-350.

8. Rajajee S.: Post-streptococcal acute glomerulonephritis: a clinical, bacteriological and serological study. Indian J Pediatr 1990, $57,775-780$.

9. Currie B., Brewster D.R.: Rheumatic fever in Aboriginal children. J Paediatr Child Health 2002, 38, 223-225.

10. Engelman D., Kiang K., Chosidow O., McCarthy J., Fuller C., Lammie P., et al.: Toward the global control of human scabies: introducing the international alliance for the control of scabies. PLoS Negl Trop Dis 2013, 7, e2167.

11. Leung V., Miller M.: Detection of scabies: a systemic review of diagnostic methods. Can J Infect Dis Med Microbiol 2011, 22, 143-146.

12. Anderson K.L., Strowd L.C.: Epidemiology, diagnosis and treatment of scabies in a dermatology office. J Am Board Fam Med 2017, 30, 78-84.

13. Sobjanek M., Sławińska M., Bykowska B., Wilkowska A., Nowicki R.: Videodermoscopy is an effective diagnostics tool for scabies. Przegl Dermatol 2016, 103, 383-386.

14. Kumpol A.: Crusted scabies in a patient with methamphetamine abuse. JAAD Case Rep 2018, 4, 480-481.

15. Gach J.E., Heagerty A.: Crusted scabies looking like psoriasis. Lancet 2000, 356, 650.

16. Farrell A.M., Ross J.S., Bunker C.B., Staughton R.C.D.: Crusted scabies with scalp involvement in HIV-1 infection. Br J Dermatol 1998, 138, 192-193.

17. Salavastru C., Chosidow O., Boffa M., Janier M., Tiplica G.: European guideline for the management of scabies. J Eur Acad Dermatol Venereol 2017, 31, 1248-1253.

18. Pipitone M.A., Adams B., Sheth A., Graham T.B.: Crusted scabies in a patient being treated with infliximab for juvenile rheumatoid arthritis. J Am Acad Dermatol 2005, 52, 719-720.

19. Markovic I., Puksic S., GudeljGracanin A., Ivana Culo M., Mitrovic J., Morovic-Vergles J.: Scabies in a patient with rheumatoid arthritis treated with adalimumab - a case report. Acta Dermatovenerol Croat 2015, 23, 195-198.

20. Roberts L.J., Huffam S.E., Walton S.F., Currie B.J.: Crusted scabies: clinical and immunological findings in seventy-eight patients and a review of the literature. J Infect 2005, 50, 375-381.

21. Nagsuk P., Moore R., Lopez L.: A case report of crusted scabies in an adult patient with Down syndrome. Dermatol Online J 2015, 21, pii: 13030/qt4kc74256.

22. Fonseca V., Price H.N., Jeffries M., Alder S.L., Hansen R.C.: Crusted scabies misdiagnosed as erythrodermic psoriasis in a 3-year-old girl with down syndrome. Pediatr Dermatol 2014, 31, 753-754.

23. Mantero N.M., Jaime L.J., Nijamin T.R., Laffargue J.A., De Lillo L., Grees S.A.: Norwegian scabies in a pediatric patient with Down syndrome, a case report. Arch Argent Pediatr 2013, 111, e141-3.

24. Guldbakke K.K., Khachemoune A.: Crusted scabies: a clinical review. J Drugs Dermatol 2006, 5, $221-227$.

25. Chosidow O.: Clinical practices. Scabies. N Engl J Med 2006, 354, 1718-1727.

26. Dupuy A., Dehen L., Bourrat E., Lacroix C., Benderdouche M., Dubertret L., et al.: Accuracy of standard dermoscopy for diagnosing scabies. J Am Acad Dermatol 2007, 56, 53-62.

27. David N., Rajamanoharan S., Tang A.: Are sexually transmitted infections associated with scabies? Int J STD AIDS 2002, 13, 168-170.

28. Mellon G., Hermet L., Toutain P.L., Dulioust A., Lespine A.: Scabies in an obese patient: how should the ivermectin dosing be adapted? Med Mal Infect 2019, 49, 286-88.

29. Park J., Park S.Y., Han J., Lee S.Y., Kim G.E., Jeong Y.S., et al.: Identifying the time to cure for patients with classic scabies after infection control intervention in acute care hospital settings. Am J Infect Control 2019, 47, 588-590.

30. Jaramillo-Ayerbe F., Berrio-Munoz J.: Ivermectin for crusted Norwegian scabies induced by use of topical steroids. Arch Dermatol 1998, 134, 143-145.

31. Marlière V., Roul S., Labrèze C., Taïeb A.: Crusted (Norwegian) scabies induced by use of topical corticosteroids and treated successfully with ivermectin. J Pediatr 1999, 135, 122-124.

32. Corbett E.L., Crossley I., Holton J., Levell N., Miller R.F., De Cock K.M.: Crusted ("Norwegian") scabies in a specialist HIV unit: successful use of ivermectin and failure to prevent nosocomial transmission. Genitourin Med 1996, 72, $115-117$.

Received: 12.02 .2019

Accepted: 7.08.2019

Otrzymano: $12.02 .2019 \mathrm{r}$

Zaakceptowano: 7.08.2019 r.

\section{How to cite this article}

Kosmala A., Szymoniak-Lipska M., Jałowska M., Dobrzyńska M., Bowszyc-Dmochowska M., Adamski Z., Żaba R.: Crusted scabies in a patient with systemic disorders - evaluation of ivermectin treatment results. Dermatol Rev/Przegl Dermatol 2019, 106, 671-679. DOI: https://doi.org/10.5114/dr.2019.92740. 